\title{
GAMBARAN STOMATITIS AFTOSA REKUREN DAN STRES PADA NARAPIDANA DI LEMBAGA PEMASYARAKATAN KELAS II B BITUNG
}

\author{
${ }^{1}$ Melky G. Junhar \\ ${ }^{2}$ Pieter L. Suling \\ ${ }^{3}$ Aurelia S R Supit
}

\author{
${ }^{1}$ Kandidat Skripsi Program Studi Pendidikan Dokter Gigi Fakultas Kedokteran \\ ${ }^{2}$ Bagian Ilmu Penyakit Kulit dan Kelamin Fakultas Kedokteran \\ ${ }^{3}$ Program Studi Pendidikan Dokter Gigi Fakultas Kedokteran \\ Universitas Sam Ratulangi Manado \\ E-mail: melky_dentistry@yahoo.com
}

\begin{abstract}
Prisoners are individuals who have been convicted of crimes and were sentenced to prison so they lost their freedom. Lost of freedom can cause stress. Stress is the ability of a person to survive under pressure without causing disturbance. Recurrent aphthous stomatitis (RAS) is a manifestation in the oral cavity which is usually triggered by some predisposing factors such as stress. This study aimed to describe recurrent aphthous stomatitis and stress among prisoners in prison class IIB Bitung. This study was cross-sectional with total sampling method. All prisoners who had experienced recurrent aphtous stomatitis (RAS) while in prison class IIB Bitung. The results showed that among the 56 respondents there were 53 male respondents (94.64\%) and 3 female respondents (5.36\%); 19 (33.93\%) got mild stress, 18 (32.14\%) moderate stress, 16 (28.58\%) severe stress, and 3 (5.35\%) very severe stress.
\end{abstract}

Keywords: prisoner, stress, recurrent aphthous stomatitis (RAS)

\begin{abstract}
Abstrak: Narapidana adalah individu yang telah terbukti melakukan tindak pidana dan kemudian oleh pengadilan dijatuhi hukuman atau pidana serta kehilangan kebebasan. Kehilangan kebebasan menimbulkan terjadinya stres pada narapidana. Stres merupakan kemampuan individu untuk bertahan dalam menghadapi berbagai tekanan tanpa mengakibatkan gangguan. Stomatitis aftosa rekuren (SAR) merupakan manifestasi yang timbul dalam rongga mulut yang biasanya dipicu oleh beberapa faktor predisposisi, salah satunya stres. Tujuan penelitian yaitu mengetahui gambaran stomatitis aftosa rekuren dan stres pada narapidana di Lembaga Pemasyarakatan (LP) Kelas IIB Bitung. Jenis penelitian ini menggunakan desain potong lintang. Semua narapidana yang pernah mengalami Stomatitis Aftosa Rekuren (SAR) saat berada di Lembaga Pemasyarakatan kelas II B Bitung. Hasil penelitian menunjukkan bahwa dari 56 responden terdapat 53 responden berjenis kelamin lakilaki $(94,64 \%)$ dan terdapat 3 responden berjenis kelamin perempuan (5,36\%). Hasil pengukuran stres menunjukkan bahwa dari 56 responden 19 responden (33,93\%) mengalami tingkat stres ringan, 18 responden (32,14\%) mengalami tingkat stres sedang, 16 responden (28,58\%) mengalami tingkat stres berat dan 3 responden (5,35\%) mengalami tingkat stres sangat berat.
\end{abstract}

Kata kunci: narapidana, stres, stomatitis aftosa rekuren.

Narapidana adalah individu yang telah terbukti melakukan tindak pidana dan kemudian oleh pengadilan dijatuhi hukuman atau pidana serta kehilangan kemerdekaan. Pengadilan mengirimkan narapidana ke rumah tahanan (Rutan) atau lembaga pemasyarakatan (LP) untuk menjalani hukuman dalam jangka waktu 
tertentu. ${ }^{1}$ Ruang gerak narapidana dibatasi selama berada di Lembaga Pemasyarakatan (LP) dan terisolasi dari masyarakat. Keadaan seperti ini dapat menyebabkan stres pada narapidana. ${ }^{2}$ Stres merupakan respon nonspesifik tubuh akibat perubahan sosial dari modernisasi. ${ }^{3}$ Setiap individu memiliki tingkat atau toleransi stres yang berbeda-beda. Tingkat stres individu mengacu pada kemampuan individu untuk bertahan dalam menghadapi berbagai tekanan tanpa mengakibatkan gangguan. ${ }^{4}$

Salah satu penyakit yang sering menyerang rongga mulut yaitu Stomatitis Aftosa Rekuren (SAR). Stomatitis aftosa rekuren merupakan penyakit mulut yang paling sering diderita manusia dengan ciri khas ulkus single atau multiple, kambuhan, kecil, bulat atau oval dengan batas jelas kemerahan, dan dasar abu-abu atau kuning. 5

Stomatitis aftosa rekuren (SAR) merupakan manifestasi yang timbul dalam rongga mulut yang dipicu oleh faktor predisposisi. Beberapa faktor predisposisi SAR yaitu kekurangan hematinik (zat besi, folat, dan vitamin $\mathrm{B}_{12}$ ), tahap menstruasi, stres, alergi, alergi makanan, dan AIDS.,

SAR merupakan kondisi umum berulang yang ditandai dengan ulkus ukuran kecil berbentuk bulat atau oval. Dasar ulkus biasanya berwarna abu-abu atau kuning. SAR dapat terjadi pada berbagai kalangan usia dengan prevalensi sangat tinggi pada negara maju. Etiologi SAR tidak sepenuhnya jelas dan sangat bervariasi tergantung faktor predisposisi.

Di Kalangan awam, SAR dikenal sebagai sariawan yang merupakan salah satu jenis ulkus yang muncul di rongga mulut. Istilah stomatitis memiliki arti peradangan jaringan lunak mulut, aphtosa yang berarti terbakar dan rekuren berarti ulkus pada rongga mulut selalu timbul tibatiba tanpa penyebab yang pasti. Berdasarkan padanan kata, SAR merupakan ulkus yang terasa nyeri muncul di sekitar rongga mulut secara tiba-tiba dan berulang. ${ }^{8,9,10}$

Etiologi SAR hingga saat ini masih tidak diketahui dengan pasti. Terdapat beberapa faktor yang dikatakan berperan dalam pemunculan SAR, yaitu genetik, defisiensi hematinik, hipersensivitas makanan, infeksi bakteri dan virus, perubahan hormonal, stres. ${ }^{11,12}$

Gambaran klinis stomatitis aftosa rekuren dibagi menjadi tiga kelompok, yaitu minor aphtae, mayor aphtae, dan herpetiform ulcers. Lesi SAR menimbulkan rasa nyeri, bentuknya bulat atau oval dengan pusat nekrotik yang dangkal disertai dengan pseudomembran warna putih kekuningan yang dikelilingi oleh daerah eritematous yang mengalami peninggian. ${ }^{11,13}$

Untuk dapat menegakkan diagnosis yang tepat dari SAR dapat dilakukan dengan cara melakukan anamnesis dan pemeriksaan fisik. Biasanya pada anamnesis pasien akan merasakan sakit pada mulutnya, tempat ulser sering berpindah-pindah dan biasanya kejadiannya selalu berulang. Pada pemeriksaan fisik dapat ditemukan ulser pada bagian mukosa mulut dengan bentuk yang oval dengan lesi yang biasanya berukuran $\pm 1 \mathrm{~cm}$. ${ }^{9,12}$

Stres merupakan salah satu terminologi yang popular dibicarakan dalam percakapan sehari-hari seiring meningkatnya modernisasi dan dinamika kehidupan. Stres diartikan sebagai respon nonspesifik tubuh akibat perubahan sosial dari modernisasi. ${ }^{5,14}$

Instrumen untuk mengukur tingkat stres berupa kuesioner. Salah satu kuesioner yang telah teruji yaitu Depression Anxiety and Stress Scale (DASS). Depression anxiety stress scale terdiri atas 42 pertanyaan yang dirancang untuk mengukur tingkatan emosional negatif dari depresi, kecemasan, dan stres. Skala stres dalam depression anxiety stress scale terdiri atas 14 pertanyaan dan sangat sensitif terhadap level penyebab kronik non spesifik. Skala stres digunakan untuk mengukur tingkat relaksasi, munculnya gangguan saraf, tingkat kemarahan, reaksi berlebihan, dan tingkat kesabaran. Hasil jawaban responden berdasarkan 
pengalaman selama seminggu akan dievaluasi dengan indeks keparahan stress , serta dihitung berdasarkan sistem skor. ${ }^{15}$

Menurut Kamus Besar Bahasa Indonesia, narapidana adalah orang terhukum karena dinyatakan bersalah oleh hakim karena tindak pidana. ${ }^{16}$

Stres yang dirasakan oleh individu yang menimbulkan upaya untuk melakukan reaksi terhadap stres yang dialaminya. Stres merupakan suatu wujud dari hubungan antara kejadian atau kondisi lingkungan dengan penilaian kognitif individu terhadap tingkat, tipe tantangan, kesulitan, kehilangan dan ancaman. Reaksi tersebut merupakan suatu aktivitas untuk melakukan penyesuaian diri terhadap situasi perangsang tertentu, yang apabila tidak dapat dilakukan dengan baik akan menyebabkan gangguan fisik maupun kejiwaan. ${ }^{14,17}$

Stres merupakan salah satu faktor predisposisi stomatitis aftosa rekuren yang dapat dialami oleh narapidana. Berdasarkan survei awal pada bulan april tahun 2014 di Lembaga pemasyarakatan Kelas II B Bitung, diketahui sebagian besar narapidana cenderung mengalami stres dan pernah mengalami stomatitis aftosa rekuren. Penelitian mengenai stomatitis aftosa rekuren dan stres pada narapidana belum pernah dilakukan di Sulawesi Utara. Berdasarkan hal-hal yang ada maka peneliti tertarik untuk melakukan penelitian tentang Gambaran Stomatitis Aftosa Rekuren dan Stres pada Narapidana di Lembaga pemasyarakatan Kelas II B Bitung.

\section{BAHAN DAN METODE PENELITIAN}

Jenis penelitian ini ialah penelitian deskriptif dengan desain cross sectional study. Penelitian dilakukan di Lembaga Pemasyarakatan Kelas II B Bitung, Jalan J P Kalangi kelurahan Tewaan, kecamatan Ranowulu kota Bitung pada bulan September 2014. Populasi dalam penelitian ini ialah para Narapidana Lembaga Pemasyarakatan Kelas II B Bitung dengan jumlah 205 orang.

Instrumen dalam penelitian ini berupa kuesioner, alat dan bahan yang digunakan dalam penelitain ini adalah alat tulis menulis dan lembar persetujuan penelitian (informed consent). Pengambilan data dilaksanakan setelah responden menerima penjelasan peneliti dan menandatangani surat pernyataan menjadi sampel peneltian (informed consent). Peneliti mengisi data reponden yang akan diperiksa pada lembar kuesioner. Kemudian peneliti mengajukan pertanyaan berdasarkan kuesioner yang bertempat di poliklinik LP, Peneliti dibantu oleh 5 orang teman.

Data yang diperoleh diolah secara univariat dan disajikan dalam bentuk tabel distribusi frekuensi.

\section{HASIL PENELITIAN}

Responden dalam penelitian ini ialah seluruh narapidana yang ada di Lembaga Pemasyarakatan Kelas IIB Bitung yang bersedia untuk diwawancarai dan berpartisipasi dalam mengisi kuesioner Stomatitis Aftosa Rekuren (SAR) dan stres sebanyak 56 responden. Karakteristik responden dilihat berdasarkan jenis kelamin, umur, dan lamanya responden ditahan di Lembaga Pemasyarakatan Kelas IIB Bitung.

Responden dengan jenis kelamin lakilaki berjumlah 53 responden (94,64\%) dan responden dengan jenis kelamin perempuan berjumlah 3 responden (5,36\%). Responden berdasarkan usia 12-60 tahun, dari 56 responden yang ada di Lembaga Pemasyarakatan Kelas IIB Bitung diketahui jumlah responden terbanyak berusia 17-25 tahun dengan 26 responden (46,43\%), sedangkan paling sedikit ialah responden yang berusia 56-65 tahun dengan 1 responden (1,79\%). Responden berdasarkan lamanya responden ditahan 048 bulan di Lembaga Pemasyarakatan Kelas IIB Bitung dari 56 responden terdapat sebanyak 20 responden (35,71\%) yang memiliki rentan waktu ditahan 7 bulan - 12 bulan dalam penahanan di (LP), sedangkan paling sedikit ialah responden dengan masa penahanan $\geq 48$ bulan dengan jumlah responden 3 (5,36\%). 
Karakteristik responden berdasarkan riwayat SAR sebulan lalu di Lembaga Pemasyarakatan Kelas IIB Bitung, dari 56 responden terdapat sebanyak 27 responden $(48,21 \%)$ yang menyatakan mengalami SAR sebulan yang lalu, sedangkan sebanyak 29 responden (51,79\%) yang menyatakan tidak mengalami SAR sebulan yang lalu.

Karakteristik responden berdasarkan riwayat SAR pertama kali, dari 56 responden terdapat sebanyak 34 responden $(60,72 \%)$ yang mengalami SAR pada saat umur remaja sedangkan terdapat sebanyak 9 responden (16,07\%) yang mengalami SAR pada saat dewasa dan sebanyak 13 responden $(23,21 \%)$ yang mengalami SAR pada saat memasuki Lembaga Pemasyarakatan (LP). karakteristik responden berdasarkan lama penyembuhan SAR di Lembaga Pemasyarakatan Kelas IIB Bitung, dari 56 responden sebanyak 26 responden (46,43\%) yang mengalami proses penyembuhan berkisar antara 1-2 minggu sedangkan sebanyak 5 responden $(8,93 \%)$ yang mengalami proses penyembuhan berkisar $>2$ minggu.

Tabel 1. Distribusi karakteristik responden berdasarkan frekuensi terjadinya SAR di Lembaga Pemasyarakatan Kelas IIB Bitung

\begin{tabular}{lrr}
\hline Frekuensi & $\begin{array}{l}\text { Jumlah } \\
\text { responden (n) }\end{array}$ & $\begin{array}{l}\text { Persentase } \\
(\%)\end{array}$ \\
\hline 1x sebulan & 21 & 37,50 \\
>1x sebulan & 5 & 8,93 \\
1x setahun & 5 & 8,93 \\
Di saat & 25 & 44,64 \\
tertentu & & \\
\hline Total & 56 & 100 \\
\hline
\end{tabular}

\section{BAHASAN}

Responden yang terlibat dalam penelitian ini berjumlah 56 responden. Sebagian besar responden yang terlibat dalam penelitian ini berjenis kelamin lakilaki, yaitu berjumlah 53 responden (94,64\%), sedangkan responden yang berjenis kelamin perempuan berjumlah 3 responden $(5,36 \%)$.
Responden pada penelitian ini yang mempunyai riwayat SAR terdiri 53 (94,64\%) responden laki-laki dan 3 responden $(5,36 \%)$ perempuan. Adanya bias dalam penelitian ini dapat terjadi karena jumlah sampel laki-laki dan perempuan tidak seimbang, sehingga perbandingan SAR berdasarkan jenis kelamin tidak dapat membuktikan literatur yang menyatakan bahwa laki-laki lebih sering terserang SAR dari perempuan dengan ratio $2: 3 .^{6-8}$

Tabel 2. Distribusi karakteristik responden berdasarkan faktor predisposisi di Lembaga Pemasyarakatan Kelas IIB Bitung

\begin{tabular}{|c|c|c|c|c|c|c|}
\hline \multirow{2}{*}{$\begin{array}{l}\text { Faktor } \\
\text { predisposi } \\
\text { si }\end{array}$} & \multicolumn{2}{|c|}{ Ya } & \multicolumn{2}{|c|}{ Tidak } & \multicolumn{2}{|c|}{ Total } \\
\hline & $\mathrm{n}$ & $\%$ & $\mathrm{~N}$ & $\%$ & $\mathrm{~N}$ & $\%$ \\
\hline \multirow[t]{2}{*}{ Alergi } & 1 & 26,7 & 4 & 73,2 & 5 & 10 \\
\hline & 5 & 9 & 1 & 1 & 6 & 0 \\
\hline \multirow[t]{2}{*}{ Trauma } & 4 & 82,1 & 1 & 17,8 & 5 & 10 \\
\hline & 6 & 4 & 0 & 6 & 6 & 0 \\
\hline \multirow[t]{2}{*}{ Genetik } & 4 & 78,5 & 1 & 21,4 & 5 & 10 \\
\hline & 4 & 7 & 2 & 3 & 6 & 0 \\
\hline
\end{tabular}

Tabel 3. Distribusi karakteristik responden berdasarkan tindakan perawatan SAR di Lembaga Pemasyarakatan Kelas IIB Bitung

\begin{tabular}{lll}
\hline $\begin{array}{l}\text { Tindakan } \\
\text { perawatan }\end{array}$ & $\begin{array}{l}\text { Jumlah } \\
\text { responden } \\
(\mathrm{n})\end{array}$ & $\begin{array}{l}\text { Persentase } \\
\%\end{array}$ \\
\hline Ya & 37 & 66,07 \\
Tidak & 19 & 33,93 \\
\hline Total & 56 & 100 \\
\hline
\end{tabular}

Tabel 4. Distribusi karakteristik responden berdasarkan jenis perawatan SAR di Lembaga Pemasyarakatan Kelas IIB Bitung

\begin{tabular}{lcl}
\hline $\begin{array}{l}\text { Jenis } \\
\text { perawatan }\end{array}$ & $\begin{array}{l}\text { Jumlah } \\
\text { responden } \\
(\mathrm{n})\end{array}$ & $\begin{array}{l}\text { Persentase } \\
\%\end{array}$ \\
\hline $\begin{array}{l}\text { Ke dokter } \\
\text { Vitamin }\end{array}$ & 5 & 13,51 \\
$\begin{array}{l}\text { Konsumsi } \\
\text { buah dan } \\
\text { sayur }\end{array}$ & 2 & 81,08 \\
\hline Total & 37 & 5,4 \\
\hline
\end{tabular}


Tabel 5. Distribusi karakteristik responden berdasarkan tindakan pencegahan SAR di Lembaga Pemasyarakatan Kelas IIB Bitung

\begin{tabular}{lll}
\hline $\begin{array}{l}\text { Tindakan } \\
\text { pencegahan } \\
\text { SAR }\end{array}$ & $\begin{array}{l}\text { Jumlah } \\
\text { responden } \\
\text { (n) }\end{array}$ & $\begin{array}{l}\text { Persentase } \\
\%\end{array}$ \\
\hline $\begin{array}{l}\text { Menjaga } \\
\text { kebersihan } \\
\text { mulut }\end{array}$ & 42 & 75,00 \\
$\begin{array}{l}\text { Menggunakan } \\
\text { obat kumur }\end{array}$ & 7 & 12,50 \\
$\begin{array}{l}\text { Tidak } \\
\text { melakukan } \\
\text { pencegahan }\end{array}$ & 7 & 12,50 \\
\hline Total & 56 & 100 \\
\hline
\end{tabular}

Tabel 6. Distribusi karakteristik responden berdasarkan tingkatan stres pada narapidana di Lembaga Pemasyarakatan Kelas IIB Bitung

\begin{tabular}{lcl}
\hline $\begin{array}{l}\text { Tingkat } \\
\text { stress }\end{array}$ & $\begin{array}{l}\text { Jumlah } \\
\text { responden } \\
\text { (n) }\end{array}$ & $\begin{array}{l}\text { Persentase } \\
\%\end{array}$ \\
\hline Normal & 0 & 0 \\
Ringan & 19 & 33,93 \\
Sedang & 18 & 32,14 \\
Berat & 16 & 28,58 \\
Sangat & 3 & 5,35 \\
berat & 56 & 100 \\
\hline Total & 56 \\
\hline
\end{tabular}

Tabel 7. Distribusi karakteristik responden yang memiliki riwayat SAR sebulan lalu berdasarkan tingkat stres pada narapidana di Lembaga Pemasyarakatan Kelas IIB Bitung

\begin{tabular}{lrlllrl}
\hline \multicolumn{7}{c}{ Riwayat SAR Sebulan } \\
Stres & \multicolumn{2}{l}{ Lalu } & \multicolumn{2}{l}{ Total } \\
& \multicolumn{1}{c}{ Ya } & \multicolumn{2}{c}{ Tidak } \\
& \multicolumn{1}{c}{$\mathrm{n}$} & $\%$ & $\mathrm{n}$ & $\%$ & \multicolumn{1}{c}{$\mathrm{n}$} & $\%$ \\
\hline Normal & 0 & 0 & 0 & 0 & 0 & 0 \\
Ringan & 10 & 37,03 & 9 & 31,03 & 19 & 100 \\
Sedang & 14 & 51,85 & 4 & 13,79 & 18 & 100 \\
Berat & 3 & 11,11 & 13 & 44,82 & 16 & 100 \\
Sangat & 0 & 0 & 3 & 100 & 3 & 100 \\
Berat & & & & & & \\
\hline
\end{tabular}

Responden yang pernah mengalami SAR lebih banyak daripada yang tidak pernah mengalami SAR. Hasil penelitian tersebut mendukung teori yang menyebutkan bahwa SAR merupakan penyakit mulut yang paling banyak dialami oleh populasi manusia dan sering ditemukan oleh klinisi. Sampai saat ini SAR masih merupakan penyakit mulut yang paling sering dialami oleh manusia sepanjang hidupnya. ${ }^{5}$

Penelitian ini mengungkapkan bahwa terdapat 56 responden yang pernah mengalami SAR tetapi hanya 27 (48,21\%) responden yang memiliki riwayat SAR sebulan lalu. Asumsi berdasarkan wawancara mengungkapkan bahwa hasil ini dipengaruhi oleh beberapa faktor misalnya trauma, stres, dan makanan.

Berdasarkan usia, responden dengan usia 17-25 dan 26-35 tahun paling banyak yang mengalami SAR. Hasil penelitian ini sesuai dengan literatur yang menyatakan bahwa munculnya SAR akan meningkat seiring dengan pertambahan usia selama dekade ketiga kehidupan (21 sampai 30 tahun).

Penelitian ini menunjukkan bahwa faktor predisposisi dari SAR yang dialami oleh responden bukan hanya satu faktor saja, tetapi juga oleh beberapa faktor predisposisi yang memicu terjadinya SAR. Dari 56 responden yang pernah mengalami SAR, sebanyak 46 responden $(82,14 \%)$ menjawab bahwa SAR yang dialami pada rongga mulutnya muncul setelah mengalami trauma dalam rongga mulut. Trauma yang sering dialami yaitu trauma karena terbentur sikat gigi saat menyikat gigi dan tidak sengaja tergigit bagian tertentu dari mukosa mulut. ${ }^{18}$ Hasil penelitian ini sesuai dengan literatur yang menyatakan bahwa sering dilaporkan munculnya SAR pada daerah yang mengalami trauma karena tergigit dan terbentur sikat gigi. ${ }^{18,19}$

Tingginya angka kejadian SAR berdasarkan faktor predisposisi trauma disebabkan karena gejala-gejala awal akibat trauma dalam rongga mulut seperti tergigit dan terbentur yang seolah-olah menusuk mukosa mulut dan langsung disertai oleh munculnya ulser pada daerah yang tauma. Proses menjadi ulser yang 
berlangsung cepat dari trauma menjadi SAR yang membuat responden menduga bahwa faktor predisposisi trauma yang mengakibatkan muncul SAR yang dialaminya. Diasumsikan juga bahwa setiap terjadi trauma maka akan menimbulkan luka. Hal ini memperkuat lagi anggapan bahwa faktor predisposisi trauma yang menyebabkan SAR pada responden. ${ }^{20}$

Sebanyak 44 responden (78,57\%) menjawab bahwa SAR yang dialaminya juga dialami oleh anggota keluarga (orang tua dan saudara) dan munculnya SAR mulai dialami sejak masa kanak-kanak. Ulser SAR yang muncul pertama kali saat kanak-kanak dan adanya riwayat SAR dari orang tua merupakan ciri-ciri dari SAR yang dipicu oleh faktor predisposisi genetik. Beberapa literatur mengungkapkan bahwa SAR yang dialami oleh orang tua akan diturunkan kepada anaknya. Saudara kandung yang mengalami SAR juga merupakan dampak dari SAR yang dialami oleh orang tua yang diturunkan kepada anaknya. Adanya hubungan antara riwayat SAR dari orang tua yang memicu SAR yang dialami anak-anaknya telah dibuktikan menggunakan Human Leukocyte Antigen (HLA) namun sampai saat ini hal tersebut baru terbukti pada beberapa grup etnik tertentu. ${ }^{19}$

Alergi terhadap beberapa makanan seperti kacang, coklat, kentang goreng, keju, susu, terigu, gandum, kopi, sereal, almond, stroberi dan beberapa makanan dari tomat dihubungkan dengan munculnya SAR pada beberapa pasien. Pada penelitian ini, sebanyak 15 responden (26,78\%) menjawab pernah mengalami SAR setelah mengonsumsi makanan tertentu. Responden mengalami gatal-gatal pada mukosa mulutnya kemudian berkembang menjadi SAR setelah mengonsumsi makanan tertentu. Beberapa literatur mengungkapkan bahwa salah satu makanan yang menimbulkan alergi dan memicu SAR yaitu ikan asin. Diperkirakan bahwa alergi terhadap ikan asin akan menyebabkan sensasi rasa gatal pada rongga mulut sehingga membuat mukosa mulut mengalami luka. Luka inilah yang diduga berkembang menjadi SAR pada rongga mulut, namun belum ditemukan literatur maupun hasil penelitian yang menyebutkan bahwa ikan dapat memicu SAR yang dialami seseorang. ${ }^{21-23}$

Penelitian ini mengungkapkan bahwa terdapat 5 responden $(8,93 \%)$ yang mengalami penyembuhan SAR setelah 2 minggu. Hasil ini mendukung studi literatur yang dilakukan oleh Scully C, dkk yang mengungkapkan bahwa SAR yang penyembuhannya lebih dari 2 minggu termasuk jenis SAR mayor dan kemungkinnannya dipicu oleh beberapa faktor salah satunya stres. ${ }^{24}$

SAR merupakan penyakit rongga mulut yang dapat sembuh sendiri dalam waktu 10-14 hari tanpa pengobatan dan dapat kambuh kembali. ${ }^{18,19,25}$ Hasil penelitian yang dilakukan menunjukkan bahwa 19 responden (33,93\%) tidak melakukan perawatan terhadap SAR yang dialami, ulser tersebut sembuh dengan sendirinya dan 37 responden (66,07\%) melakukan perawatan khusus terhadap SAR. Data ini sesuai dengan sebagian besar literatur yang menyebutkan bahwa SAR tidak memerlukan perawatan. Perawatan terhadap pasien SAR pada umumnya bersifat non spesifik dan dilakukan dengan tujuan menghilangkan rasa sakit, mengurangi besar dan lamanya ulser. ${ }^{25,18-20}$ Sedangkan tindakan pencegahan yang dilakukan untuk mengurangi tingkat rekurensi dari SAR yaitu 42 responden (75\%) menjaga kebersihan mulut dan 7 responden (12,50\%) menggunakan obat kumur dan 7 responden (12,50\%) tidak melakukan apapun. Tindakan pencegahan dengan menjaga kebersihan rongga mulut bertujuan untuk mencegah berkembang biaknya bakteri-bakteri patogen rongga mulut yang dapat memicu terjadinya ulser dan penyakit mulut lainnya. ${ }^{24,26}$ Selain itu, banyak juga para ahli yang menyatakan bahwa obat kumur dapat mengurangi rasa sakit dan tingkat rekurensi dari SAR, dengan dosis yang telah ditetapkan. ${ }^{26,27}$ Hasil penelitian juga menunjukkan bahwa 2 
responden (3,57\%) merawat SAR yang mereka alami dengan meningkatkan konsumsi buah dan sayur. Hasil ini sesuai dengan literatur yang menyebutkan bahwa untuk mencegah atau mengurangi timbulnya SAR dapat diimbangi dengan banyak mengonsumsi buah dan sayur, sebab faktor lain penyebab timbulnya SAR adalah defisiensi nutrisi. ${ }^{28}$

Berdasarkan tabel 14 tingkat stres pada narapidana di Lembaga Pemasyarakatan Kelas IIB Bitung menunjukkan sebanyak 14 responden $(77,77 \%)$ memiliki riwayat SAR sebulan lalu dengan tingkat stres sedang. Hasil ini apabila dibandingkan dengan penelitian Refeatun Nissa tentang faktor stres sebagai salah satu predisposisi SAR di Universitas Sumatera Utara pada tahun 2011 menunjukkan bahwa sebagian besar mahasiswa $(77,8 \%)$ memiliki riwayat SAR yang dipicu stres dengan tingkatan stres tinggi, tetapi terdapat 3 responden dengan tingkat stres sangat berat yang tidak mengalami SAR sebulan yang lalu. Hasil ini menunjukkan perbedaan tingkat stres yang sangat berbeda antara responden dikarenakan responden berada pada kondisi yang berbeda. Responden pada penelitian Refeatun Nissa merupakan mahasiswa sehingga memiliki beban stres yang dipengaruhi oleh beban belajar dan kehidupan sosial sebagai pelajar sedangkan responden pada penelitian ini sudah terbiasa dengan kehidupan sosial di dalam Lembaga Pemasyarakatan yang penuh dengan peraturan. ${ }^{29}$

Pada tiga responden yang memiliki tingkatan stres sangat berat tidak terdapat riwayat SAR sebulan yang lalu. Hasil wawancara menunjukkan bahwa responden melakukan tindakan pencegahan dan perawatan seperti mengonsumsi vitamin, menjaga kebersihan mulut dan menggunakan obat kumur.

\section{SIMPULAN}

Berdasarkan penelitian yang telah dilakukan maka dapat disimpulkan bahwa dari 56 responden di Lembaga Pemasyarakatan Kelas IIB Bitung yang mengalami Stomatitis Aftosa Rekuren
(SAR) dengan tingkat stres ringan berjumlah 19 responden (33,93\%), sedang berjumlah 18 responden (32,14\%), berat 16 responden $(28,58 \%)$, dan sangat berat berjumlah 3 responden (5,35\%).

\section{SARAN}

1. Bagi instansi di Lembaga pemasyarakatan untuk lebih memperhatikan peningkatan mutu kesehatan narapidana khususnya penyediaan tenaga kesehatan di (LP).

2. Bagi masyarakat khususnya masyarakat yang berada di Lembaga Pemasyarakatan untuk lebih menjaga kebersihan khusunya kebersihan gigi dan mulut dan sanitasi yang berada di lembaga pemasyarakatan.

\section{DAFTAR PUSTAKA}

1. Samosir CD. Sekelumit tentang penology dan pemasyarakatan. Bandung: Nuansa Aulia; 2012.p.131.

2. Siswati T, Abdurrohim. Masa hukuman dan stress pada narapidana. Proyeksi J 2004; 4(2): 95-106.

3. Selye H. Stress and the general adaptation syndrome. British Medical Journal June 1950; 1383-92.

4. Jusuf M, Paramata N, Ramli A. Studi epidemiologis stress, toleransi stress dan stressor psikososial pada pelajar sekolah lanjutan atas di kota Gorontalo. Jurnal Health and Sport 2012;5(2):1-10

5. Segarahayu RD. Pengaruh manajemen stres terhadap penurunan tingkat stres pada narapidana di lpw malang. Universitas Negeri Malang. Malang. [serial online] 2013;h.1-15. [diakses 19 juni 2014]. Tersedia dalam: URL: http://jurnal-

online.um.ac.id/data/artikel/artikelDEB 288149FBAA98C9CB27EB18035D95 A.pdf

6. Scully C, Cawson RA. Atlas bantu kedokteran gigi: Penyakit mulut. Jakarta: Hipokrates; 2013.p.25-6.

7. Jurge S, Kuffer R, Scully C, Porter SR. Recurrent aphthous stomatitis. Oral disease 2006; 12(1):1-21.

8. Han RP, Hwu YJ, Peng NH, Tseng KY, 
Pai LW, Chiu SC. Effectiveness of vitamin B12 on recurrent aphtous stomatitis in long term care: a systematic review. Taiwan Joanna Briggs 2011:1-15.

9. Matute RA, Alonso ER. Recurrent aphtous stomatitis in rheumatology. Rheumatol clinica 2011;7(5):323-8.

10.Harty FJ, Ogston R. Kamus kedokteran gigi. Jakarta: Penerbit Buku Kedokteran; 1995.p.293.

11.Lewis MAO, Jordan RCK. Ulceration. In: A colour handbook of oral medicine. California: University of California san Fransisco. 2004;p.24-5.

12.Laskaris G. Aphtous stomatitis. In: Katsambas AD, Lotti TM. European handbook of dermatological treatmeants $2^{\text {nd }}$ ed. America: Springer; 2003.p.48-51.

13.Sridhar T, Elumalai M, Karthika B. Recurrent aphthous stomatitis: a review. Biomedical and Pharmacology Journal 2013; 6(1):17-22.

14.Yusoff MSB. Stress, stressor and coping strategies among secondary school students in a Malaysian government secondary school initial findings. ASEAN Journal Psychiatry 2010 December; 11(2):1-15.

15.Lovibond SH, Lovibond PF. Manual for the depression anxiety stress scales, 2 nd ed. Sydney: Psychology foundation; 1995.

16.Kamus besar bahasa Indonesia. Pusat bahasa, Departemen pendidikan nasional. Jakarta. 2008.p.996.

17.Wirawan A, Nurulita U, Astuti R. Hubungan hygiene perorangan dengan sanitasi lapas terhadap kejadian penyakit herpes di lapas wanita kelas II a semarang. Jurnal Unimus 2011;1(7):59-70.

18.Scully C. Aphtous ulcers. Medscape. 2013;1-5. Available from URL: http://emedicine.medscape.com/article/ 867080-overview.

19.Field A, Longman L. Oral ulceration. In:
Tyldesley's oral medicine 5th ed. Oxford: Oxford University Press. 2003; p.52-8.

20.Cawson RA, Odell EW. Diseases of the oral mucosa: non-infective stomatitis. In: Cawson's essentials of oral pathology and oral medicine. 7th ed. Oxford: Elsevier Science; 2002;p.1925.

21.Sumintarti, Marlina E. Hubungan antara level estradiol dan progesterone dengan stomatitis aftosa rekuren. Dentofas 2012; 11(3):137-41.

22.Yekti M, Erlita P. 45 masalah dan solusi penyakit gigi dan mulut. Yogyakarta: Andi Offset; 2013.p.101.

23.Scully C, de Almeida OP, Bagan J, Dioz PD, Taylor AM. Ulcers and erosions: aphtae. In: Oral medicine and pathology at a glance. West Sussex: Wiley-Blackwell. 2010;p.56-7.

24.Scully C, Gorsky M, Nur FL. The diagnosis and management of recurrent aphthous stomatitis. JADA February 2003;134:200-7.

25.Hurlbutt M, Thomsen L. Demystifying recurrent oral ulcerations. ADA CERP PennWell [serial online]. 2007 [cited 2013 May 13]; 4: 1-9. Available from: http://www.ineedce.com/course/1430/P DF/DemystRecurOralUlceratns.pdf.

26.Scully C. Aphthous ulceration. N Engl J Med. 2006;355(2):165-72

27.Jurge S, Kuffer R, Scully C, Porter SK. Mucosal Disease Series; Number VI Recurrent Aphthous Stomatitis. 2004.p.3.

28. Wray D, Ferguson MM, Mason DK, Hutcheon AW,Dagg JH. Recurrent aphthae: treatment with Vitamin B12, folic acid and iron. Br Med J, 1975; 2:490-493.

29.Nisa R. Stomatitis aftosa rekuren yang dipicu oleh stres pada mahasiswa kedokteran gigi Universitas Sumatera Utara [skripsi]. Medan: Universitas Sumatera Utara, 2011. 